\title{
The effects of island forest restoration on open habitat specialists: the endangered weevil Hadramphus spinipennis Broun and its host-plant Aciphylla dieffenbachii Kirk
}

Emily D Fountain, Jagoba Malumbres-Olarte, Robert H Cruickshank, Adrian M Paterson

Human alteration of islands has made restoration a key part of conservation management. As islands are restored to their original state, species interactions change and some populations may be impacted. In this study we examine the coxella weevil, (Hadramphus spinipennis Broun) and its host-plant Dieffenbach's speargrass (Aciphylla dieffenbachii Kirk), which are both open habitat specialists with populations on Mangere and Rangatira Islands, Chathams, New Zealand. Both of these islands were heavily impacted by the introduction of livestock; the majority of the forest was removed and the weevil populations declined due to the palatability of their host-plant to livestock. An intensive reforestation program was established on both islands over 50 years ago but the potential impacts of this restoration project on the already endangered $H$. spinipennis are poorly understood. We combined genetic and population data from 1995 and 2010-2011 to determine the health and status of these species on both islands. There was some genetic variation between the weevil populations on each island but little variation within the species as a whole. The interactions between the weevil and its host-plant populations appear to remain intact on Mangere, despite forest regeneration. A decline in weevils and host-plant on Rangatira does not appear to be caused by canopy regrowth. We recommend that (1) these populations be monitored for ongoing effects of long-term reforestation, (2) the cause of the decline on Rangatira be investigated, and ( 3 ) the two populations of weevils be conserved as separate evolutionarily significant units. 
2 Emily D. Fountain ${ }^{1,3 *}$, Jagoba Malumbres-Olarte ${ }^{2,3}$, Robert H. Cruickshank ${ }^{3}$, and Adrian M. Paterson ${ }^{3}$

$3 \quad{ }^{1}$ Department of Forestry and Wildlife Ecology, University of Wisconsin-Madison, Madison, WI 53706, 4 USA

$5 \quad{ }^{2}$ Center for Macroecology, Evolution and Climate, Natural History Museum of Denmark, University of 6 Copenhagen, DK-2100 Copenhagen E, Denmark

$7 \quad{ }^{3}$ Department of Ecology, Faculty of Agriculture and Life Sciences, Lincoln University, Lincoln 7647, 8 Christchurch, New Zealand

9 *corresponding author: efountain@gmail.com, +17173427959 
11 Island restoration is a key focus of conservation biology. Often islands are home to endemic flora and

12 fauna which may be heavily impacted by human modification and introduced species (Hutton et al.

13 2007). Although restoring an island to a pre-human state is ideal, its restoration is not straightforward

14 (Lawton 1997) given a lack of information on species interactions and pre-human community

15

\section{Introduction}

composition and ecosystem conditions. Islands are unlikely to ever be fully restored to their previous ‘pristine' states (Atkinson 1990). The dynamic nature of colonization from the mainland (Sinclair \& Byrom 2006) and a relative lack of literature regarding long-term management also hinder island restoration (Simberloff 1990).

Despite these constraints, successful restoration has been achieved on small scales (Simberloff 1990).

Extensive ecological research is necessary for restoration efforts to be successful, and also competent genetic management of island species is pivotal for long-term success (Jamieson et al. 2006). Genetics plays an important role in ecology and conservation (Frankham et al. 2002). The loss of genetic variation, common among island populations with low effective population sizes $\left(\mathrm{N}_{\mathrm{e}}\right)$, can decrease fitness and lower ability to adapt to changing environments (Pertoldi et al. 2007). Island restoration often involves the translocation or captive rearing of organisms that are already genetically depauperate (Jamieson et al. 2006). Understanding of the genetic characteristics of species involved in island restorations is vital for long-term viability of the species, and the success of a restoration project. Islands within the New Zealand archipelago have been actively restored for many years, using pest eradication, replanting, translocation, captive rearing and reintroductions (Towns et al. 2012). One group of such islands is the Chatham Islands (Chathams), which is approximately $800 \mathrm{~km}$ east of New 
31 Zealand's South Island and consists of two large populated islands (Chatham and Pitt) and a series of 32 smaller, uninhabited islands. The Chathams have a history of intense geological activity that resulted in 33 frequent submerging and re-emerging of the islands (Heenan et al. 2010). The most recent emergence 34 of the smaller islands, such as Mangere, is thought to have been between 3.0 and 2.0 Ma (Heenan et al. 35 2010). Two of the Chatham islands, Rangatira and Mangere, have been under restoration since 1961 36 and 1968, respectively. The two islands are home to several rare birds [e.g. Petroica traverse (Chatham 37 Island black robin], plants [e.g. Myosotidium hortensia (Chatham Island forget-me-not)] and 38 invertebrates [e.g. Amychus spp. (Chatham's giant click beetle)].

39 The coxella weevil (Hadramphus spinipennis Broun 1911) is a large, flightless weevil endemic to the 40 Chatham Islands. There are four species in the genus Hadramphus (Craw 1999), all endemic to New

41 Zealand, three of which are listed as threatened or vulnerable, including H. spinipennis (Hitchmough et al. 2007). The extant populations of this species are found on Rangatira, Little Mangere and Mangere Islands, but the weevil was also historically recorded on Pitt Island in 1900 (Emberson et al. 1996).

44 Surveys of Mangere and Rangatira Islands (Schöps 1998) suggested that the weevil was thriving with 45 an estimate of over 10,000 weevils found in the 1995/1996 summer on Mangere Island (Schöps 2002) . 46 The weevil is associated with the plant Dieffenbach's speargrass (Aciphylla dieffenbachii), which is 47 found in open habitats on the islands. However, it has also been sighted on Pseudopanax chathamicum 48 Kirk (Araliacene) several hundred meters away from A. dieffenbachii (A.Liddy, G. Taylor pers. 49 comm.; Emberson et al., 1996). Choice tests between A. dieffenbachii and P. chathamicum suggest that 50 Pseudopanax is most likely not a viable host plant for this weevil (Schöps et al. 1999). Hadramphus

51 spinipennis is often found during September to February, feeding and mating on its host plant on 52 warm, humid nights (Schöps et al. 1999). 
53 Schöps (2000) performed behavioral and ecological studies on $H$. spinipennis and its host plant, $A$.

54 dieffenbachii, on Mangere Island between 1993 and 1997, and on Rangatira Island in the summer of

$551995 / 6$. The main driver for this study was the observation of local extinctions of the host-plant on

56 Mangere, which were thought to be caused by the weevil. Local extinctions of the host-plant was

57 caused by the weevils before relocating to a new patch of $A$. dieffenbachii (Schöps 1998). Schöps

58 (2000) recommended, as part of the conservation management strategy (Department of Conservation

59 1999), that $H$. spinipennis and $A$. dieffenbachii should be monitored every three to four years on

60 Mangere and Rangatira to ensure that the regenerating forests do not affect the population dynamics

61 and survival of the weevil and its host-plant.

62 Our study was conducted 13 years after the initial research by Schöps (2000) and has two main aims:

63 (1) to measure the genetic similarity between the two populations and the genetic diversity within the

64 species as a whole, and (2) determine if the current population dynamics are consistent with those

65 found by Schöps and whether they support her original prediction of stable metapopulation dynamics.

66 We hypothesize that (1) geographic isolation inhibits gene flow between weevil populations and (2)

67 loss of open-habitat has caused a decline in the A. dieffenbachii populations defined by Schöps over a

68 decade ago. We performed DNA analysis on weevils from both islands and repeated the surveys

69 conducted on Mangere and Rangatira Island. Our study explores the possible negative impacts of

70 restoration on an endangered invertebrate by incorporating a genetic and ecological approach.

71 Methods

72 Site descriptions

73 Rangatira (South East) Island is 219 ha and was heavily farmed until its purchase by the New Zealand

74 government in 1953, after which all livestock were removed in 1961 (Department of Conservation 
75 2012) (Fig. 1). Much of the original forest was destroyed for farming and many of the native plants that

76 remained were grazed by livestock. Currently, the island is mostly covered by remnant or regenerating

77 forest and A. dieffenbachii is limited to the coastal cliffs and rocky shores.

78 Mangere Island is 113 ha and surrounded by cliffs, with the highest cliff reaching $286 \mathrm{~m}$ (Fig. 1). The

79 island was once covered with native forest but $90 \%$ of the forest was burned for sheep farming and

80 many of the native vascular plants and megaherbs were suppressed by heavy grazing (Ritchie 1970).

81 Several plants, such as $A$. dieffenbachii, started to regenerate with the removal of livestock in 1968 and

82 an intensive forest planting program was implemented in 1974 (Butler \& Merton 1992). Aciphylla

83 dieffenbachii grows along the steep, rocky cliffs of Mangere and in the open grasslands. The plant has

84 a patchy distribution over the whole island.

85 Survey of Hadramphus spinipennis and Aciphylla dieffenbachii

86 Rangatira (South East) Island (14-19 February 2010) and Mangere Island (17-23 February 2011) were

87 surveyed for $A$. dieffenbachii during the day. The search was restricted to coastal and open areas where

88 A. dieffenbachii has been documented to grow (Schöps 2000). Due to adverse weather conditions, the

89 high cliffs of both islands could not be surveyed although on Rangatira, although there had been

90 reports of a large $A$. dieffenbachii population on North Summit.

91 When plants were found, the quantity and state of flowering and a visual assessment of plant size were

92 made. Plants were searched for signs of weevil feeding and activity, in particular the characteristic

93 margin feeding of $H$. spinipennis (Schöps 2000). Although other herbivores can be found on $A$.

94 dieffenbachii, the feeding pattern of $H$. spinipennis is distinctly different and well documented by

95 photograph making feeding signs easily observable (Fig. 2). Each plant was photographed and the

96 surrounding area was searched for new seedlings. GPS coordinates of major plant clusters were 
97 recorded (Table S1). At night, starting at 22:00, known A. dieffenbachii populations were visually

98 searched for H. spinipennis individuals. Data collection on Mangere was conducted in the same 99 manner as on Rangatira. All locations where A. dieffenbachia and H. spinipennis had previously been 100 recorded were visited and surveyed.

101

102

103

104 105 106 107 108 109 110 111 112 113 114 115 116

117 Biotechnologies) and deionized water to bring the total reaction volume to $25 \mu 1$.

\section{DNA collection and PCR}

Due to collection restrictions of protected species by the Department of Conservation and also local imi/iwi, weevils for DNA analysis were limited to 15 individuals captured per island. Adult $H$. spinipennis range from $18-22 \mathrm{~mm}$ in length. Individuals were randomly selected from different subpopulations on the islands; the tarsal claw and the first two segments of the tarsus were removed using ethanol-cleaned scissors and the weevil was then released. Previous work has shown that a tarsal clip has no known negative impacts on the weevils (Fountain et al. 2013). Clips were stored in propylene glycol and, when returned to the laboratory, were washed with $95 \%$ ethanol and then stored at $-20^{\circ} \mathrm{C}$ in $95 \%$ ethanol. Each tarsal clip was cut into several pieces using a sterile scalpel blade and then transferred into a $1.7 \mathrm{~mL}$ Eppendorf tube. A QIAmp DNA Investigator Kit (Qiagen, Auckland, catalog \# 56504) was used for DNA extraction following the manufacturer's protocol for tissue samples.

Two mitochondrial genes, cytochrome $c$ oxidase subunit I (COI) and cytochrome b (cytb), and one nuclear gene, internal transcribed spacer 2 (ITS2), were amplified by polymerase chain reaction (PCR). For all PCRs, $2.5 \mu \mathrm{l}$ of the DNA extraction was added to the following: $2.5 \mu \mathrm{L}$ of $0.25 \mathrm{mM}$ of dNTPs, $.2 \mu \mathrm{l}$ of polymerase, $1 \mu \mathrm{L}$ of $20 \mu \mathrm{M}$ for each primer, $2.5 \mu \mathrm{L}$ of $10 \mathrm{x}$ PCR buffer $(i$-taq, iNtRON 
118 COI was amplified using the primers LCO1490 and HCO2198 (656 base pair fragment) (Folmer et al. 119 1994). The PCR cycle was $94^{\circ} \mathrm{C}$ for 3 min followed by 35 cycles of $94^{\circ} \mathrm{C}$ for $45 \mathrm{~s}, 45^{\circ} \mathrm{C}$ for $45 \mathrm{~s}$ and $12072^{\circ} \mathrm{C}$ for $1 \mathrm{~min} 20 \mathrm{~s}$, with a final extension at $72^{\circ} \mathrm{C}$ for $5 \mathrm{~min}$. The primers $\mathrm{CB} 1$ and $\mathrm{CB} 2$ (432 base pair 121 fragment) (Simon et al. 1994) were used to amplify cytb. The PCR cycle was $94^{\circ} \mathrm{C}$ for 3 min followed 122 by 40 cycles of $94^{\circ} \mathrm{C}$ for $30 \mathrm{~s}, 49^{\circ} \mathrm{C}$ for $45 \mathrm{~s}$ and $72^{\circ} \mathrm{C}$ for $1 \mathrm{~min}$, with a final extension at $72^{\circ} \mathrm{C}$ for 5 $123 \min$.

124 Due to the difficulty in amplifying a large fragment of ITS2 using the original primer set, a new genus125 specific primer set was developed for a 450 base pair fragment of ITS2 (Table 1) (See Appendix S1 for 126 primer design details). The PCR mixture and cycle for these primers were the same as those for ITS3 127 and ITS4, except that the annealing temperature was decreased to $54^{\circ} \mathrm{C}$. Every PCR reaction included a 128 negative (water) control with no DNA.

\section{Molecular Data Analysis}

130 Sequence chromatograms for 30 COI, 16 cytb and 25 ITS2 sequences were visualized using FinchTV

1311.4 (Geospiza) and forward and reverse sequences were manually aligned in Mega 5.05 (Tamura et al. 132 2011). No insertions, deletions or stop codons were found for COI or cytb. Within ITS2 a variable AT 133 short tandem repeat (STR) was found in the middle of the sequences. Short tandem repeats may have 134 higher mutation rates compared to the flanking regions which may interfere with the phylogenetic 135 signal (Selkoe \& Toonen 2006) so we conducted preliminary analysis on the ITS2 data set with and 136 without the STR. Preliminary phylogenies were constructed in MEGA from a Kimura two-parameter 137 (K2P) distance matrix (Kimura 1980) using neighbor joining (NJ) with 1,000 bootstrap replicates. No 138 differences were found in the ITS2 analysis when the STR was removed; we chose to use the dataset 
139 without the STR for additional analysis to be confident the STR would not interfere with the 140 phylogenetic inference.

141 For Bayesian analysis, the COI data set was reduced to 16 sequences to match them with the cytb 142 sequences. Sequences of the two genes were then concatenated in R 2.13.2 (R Development Core 143 Team 2011). The concatenated mitochondrial sequence data were analyzed separately from the ITS2 144 data because they are independently evolving loci and also have differences in mutational rates. The 145 ITS2 analysis was performed on the full set of 25 sequences. Bayesian analyses were performed using 146 Beast 1.7.1 (Drummond et al. 2012). The best partitioning scheme and evolutionary model were found 147 with PartitionFinder (Lanfear et al. 2012) using the corrected Akaike Information Criterion (AICc) for 148 COI and cytb. The Kimura three-parameter (K81) model (Kimura 1981) was chosen with no 149 partitioning between the concatenated genes (known collectively below as mtDNA). Since ITS2 is not 150 a protein coding gene it was not considered for partitioning and the best fit evolutionary model was 151 found using the AICc with jModeltest 2.1.1 (Darriba et al. 2012), which identified the symmetrical 152 (SYM+G) model (Zharkikh 1994) with gamma distribution as the optimal model.

153 The mtDNA and ITS2 data were analyzed under a strict molecular clock with a coalescent (constant 154 population size) tree prior. For each gene, four replicate runs of a chain run for 50 million generations 155 were performed, sampling every 2000 generations. Convergence and effective sample size of each 156 parameter was assessed in Tracer 1.5 and samples from the four runs were pooled using Log Combiner 157 1.7.2. After discarding the initial $10 \%$ as burn-in, a maximum clade credibility tree was compiled in 158 TreeAnnotator 1.7.1 (Drummond et al. 2012).

159 For the mitochondrial data, two Bayesian analyses were conducted to provide estimates of divergence 160 time using (i) the geological evidence and the timing of the volcanic emergence of Mangere, 3-2 
161 million years ago (Heenan et al. 2010), and (ii) the standard invertebrate mitochondrial rate of 0.0115

162 substitutions/site/million years (Brower 1994). For geological dating, priors were set to allow tree

163 calibration using direct input of a fixed date for specific nodes; the root of the tree was constrained to

164 no older than 3 million years with uniform prior. Since we aim to estimate the split between the

165 Rangatira and Mangere populations a distribution of dates was not used as Mangere did not emerge

166 until 3 million years ago at the earliest. All analyses were performed in BEAST 1.7.2 (Drummond et

167 al. 2012) using the same model and partitioning scheme employed in the previous analysis. Four

168 independent runs consisting of a chain run for 50 million generations were conducted, sampling every

1692000 generations. Maximum clade credibility trees were generated in the same manner as in the

170 previous analysis.

171 Pairwise genetic distances for mtDNA were taken from the Bayesian maximum clade credibility tree

172 using PASSaGE 2.0 (Rosenberg \& Anderson 2011). A Neighbor-Net network of ITS2 haplotypes was

173 generated using SplitsTrees 4.12.3 (Huson \& Bryant 2006) to visualize conflicting patterns in the

174 phylogenetic signal. Distances for the Neighbor-Net network were calculated under the generalized

175 time reversible (GTR) model and no rate heterogeneity among sites.

\section{Results}

177 Survey

178 Rangatira

179 Three locations were found to have subpopulations of $A$. dieffenbachii: East Clears, West Clears, and

180 West Landing (subpopulations A, B, C in Fig. 3). Subpopulation A showed signs of heavy weevil 181 herbivory on all plants. In subpopulation B only a few plants showed signs of weevil damage, whereas 
182 subpopulation $\mathrm{C}$ had no weevil feeding damage. Table 3 provides a detailed description of the number 183 of plants, size of plants, and flowering state for the A. dieffenbachii populations.

184 In subpopulation A, $29 \mathrm{H}$. spinipennis were found feeding and mating on the plants. The male: female 185 sex ratio of the weevils was 15:14. In subpopulation B, three out of the nine major A. dieffenbachii 186 groups had weevils. Group 1 had two males and two females: one pair breeding and the other two 187 feeding. Group 4 had one breeding pair, and group 9 had one male feeding.

188 West Landing was searched for two nights but no weevils were found (Fig. 3). One male $H$. 189 spinipennis was found on Pseudopanax chathamicus, approximately 250 meters from the nearest $A$. 190 dieffenbachii at West Landing.

191 Mangere

192 Seven subpopulations of $A$. dieffenbachii were identified on Mangere (Fig. 4). Feeding signs were 193 observed in plants from all subpopulations. In addition to the plants found in the seven subpopulations, 194 a few individual plants were also found scattered along the south-east coast of the island but had no 195 evidence of weevil feeding damage (Fig. 4). A detailed description of the A. dieffenbachii populations, 196 including number of plants, size of plants and flowering state, is provided in Table 4.

197 Individuals of $H$. spinipennis were found in five of the seven A. dieffenbachii subpopulations. The 198 observed number of weevils reached 26 in location 1, which corresponded to subpopulation 1 of $A$. 199 dieffenbachii. Ten specimens were counted in locations 4, 6 and 3, and only two in location 2 . The 200 male: female sex ratio ranged from 19:7 in location 1, through 8:6 in location 4 , to 1:1 in locations 3 201 and 2. Weevils were observed feeding and mating in all locations except for location 2, where the two 202 individuals were feeding on separate plants. 
204 In total, 30 specimens of $H$. spinipennis were successfully sequenced for COI, 16 for cytb and 25 for 205 ITS2. For COI, a 656 bp fragment was obtained, which had three variable sites, two of which were 206 parsimony informative. Base frequency means for COI were unequal and AT-rich $(\mathrm{T}=35.0 \%$, $207 \mathrm{C}=19.6 \%, \mathrm{~A}=30.3 \%$ and $\mathrm{G}=15.1 \%$ ); a chi-square test confirmed heterogeneity of base frequencies 208 across all taxa (d.f. $=87, p=1.00$ ). For cytb, a 432 bp fragment was obtained, which had one variable 209 site, which was parsimony informative. Base frequency means for cytb were unequal and AT-rich $210(\mathrm{~T}=36.6 \%, \mathrm{C}=22.2 \%, \mathrm{~A}=29.3 \%$, and $\mathrm{G}=11.9 \%)$; a chi-square test confirmed heterogeneity of base 211 frequencies across all taxa (d.f. $=45, p=1.00$ ). The $30 \mathrm{COI}$ sequences showed little variation with only 212 two individuals sharing a single nucleotide difference between themselves and the rest of the samples. 213 However, for cytb there was a clear difference at one nucleotide in all samples between individuals 214 from each of the two islands. The pairwise genetic distances in the concatenated mitochondrial genes 215 were low with a mean of 0.002 ( $\max 0.003)$ substitutions/site between the two island populations. The 216 maximum P-distance within each island was 0.001 substitutions/site.

217 After the removal of the AT variable repeat, a $428 \mathrm{bp}$ fragment was obtained for ITS2, which contained 21824 variable sites, 17 of which were parsimony informative. Four indels were found in the sequences, 219 two from an individual on Rangatira and two from an individual on Mangere. The Neighbor-Net 220 network does not show strong genetic structure within or between the islands (Fig. 5). The results of 221 the Neighbor-Net network (Fig. 5) suggest that there may be a complicated signal between the two 222 islands represented by the network separating the two groups.

223 The maximum clade credibility trees were very similar in topology to the NJ trees; due to the splitting 224 of zero-length branches in the maximum clade credibility trees we opted to display the NJ trees. The 
225 mitochondrial tree shows a weakly-supported split between the two islands (Fig. 6a), and the branch

226 length separating the two islands is extremely small at 0.002 substitutions/site. The universal

227 mitochondrial rate for invertebrates of 0.0115 substitutions/site/million years places the origin of this

228 split around 1,300 BP (95\% HPD 0.000-0.0139 BP) and the geological time calibration of 4 million

229 years places it around 600 BP (95\% HPD 0.0001-0.0016 BP) (Fig. 6a, Table 2). The ITS2 tree shows a

230 lack of resolution and does not support any split between the two islands (Fig. 6b). There is no

231 evidence for genetic differentiation in COI and ITS2 among the subpopulations for each island

232 [subpopulations A, B, C for Rangatira and subpopulations 1-7 for Mangere (Figs. 3 and 4)].

233 Discussion

234 The genetic analysis shows a population of weevils that is highly similar across the islands with only a 235 small amount of difference between the two islands in the mitochondrial genes. A genetic difference

236 between the weevil populations of Mangere and Rangatira has been previously reported for a different

237 section of the COI gene (Goldberg \& Trewick 2011). The analysis with the two concatenated

238 mitochondrial genes showed a strong support for a split between the two islands. This difference is not

239 seen in the nuclear gene ITS2; however, due to the longer coalescent times of nuclear genes compared

240 to mitochondrial genes, there may have been insufficient time for ITS2 to achieve reciprocal

241 monophyly. Although some signal interference in the ITS2 gene caused by incomplete lineage sorting

242 and recent divergence can skew the resulting phylogeny, there is still strong support for a group that

243 includes two individuals, one from each island. Further molecular work should be conducted on more

244 nuclear genes to discover a clearer signal of genetic differentiation between the two islands.

245 The difference in the mitochondrial and nuclear gene trees can be explained by the four times faster

246 coalescence time in mitochondrial genes compared to nuclear genes (Ballard \& Whitlock 2004). The 
247 island split in the mitochondrial gene tree may be the result of the two populations having no gene

248 flow. Given the faster mutation rate of mitochondrial genes versus the nuclear genes (Moriyama \&

249 Powell 1997), reproductive isolation is likely to lead to faster differentiation of the mitochondrial

250 genes. In the future, this split may become evident in the slower evolving nuclear genes if the

251 populations remain genetically isolated. Currently the populations of the weevil and its host plant on

252 Rangatira are not as heavily monitored as they are on Mangere. If the Rangatira and Mangere

253 populations are confirmed to be genetically isolated, it is of utmost importance to take conservation

254 measures to make sure that both populations have similar chances of survival.

255 Both methods of dating the separation between individuals on the two islands using the mitochondrial

256 genes date the mean time for this split as rather recent, in the last few thousand years. This timing

257 approximately coincides with the arrival of humans and introduced mammals, particularly Polynesian

258 rats, which are known to predate Hadramphus weevils (Towns 2009). Calibrating the molecular clock

259 using the geological age of 4 million years as the last emergence of the islands gave a smaller $95 \%$

260 confidence interval. Given that using a universal mitochondrial rate is fraught with problems, such as

261 variation between genes, differences depending on substitution model used and the universal rate does

262 not account for variance in coalescent times (Papadopoulou et al. 2010), geological dating can offer a

263 better estimation of the time of separation between the two islands when applying the correct

264 distribution to account for dating uncertainty (Ho 2007).

265 The lack of genetic diversity found within H. spinipennis may be a result of population decline in the

266 weevils. A likelihood of population decline is supported by the extinction of populations of $H$.

267 spinipennis from Pitt Island in the late 1800s due to the loss of habitat and habitat modification from

268 humans. Loss in genetic variation and extinction of populations points directly to a population

269 bottleneck in H. spinipennis. 
270 The results of this study suggest that there has been no decline in the number of the H. spinipennis and

271 A. dieffenbachii populations surveyed on Mangere and population numbers have not been affected by

272 the forest regeneration. The weevil has a consumer-resource metapopulation relationship with its host

273 plant and will decimate populations of $A$. dieffenbachii before moving onto another population of

274 plants (Schöps 1998). Metapopulation theory suggests that as long as recolonization by the consumer

275 exceeds or equals the extinction rate of the resource, the metapopulation will persist (Taylor 1990). On

276 Mangere, there is evidence for subpopulations going extinct while new A. dieffenbachii populations

277 have arisen which suggests a dynamic system of localized host-plant exploitation, extinction, and

278 weevil dispersal.

279 On Rangatira, there has been a decline in both H. spinipennis and A. dieffenbachii populations.

280 Although two of the populations (A \& B) of A. dieffenbachii were found in 1995 and 2010, the plants

281 were in decline in 2010 with no flowering and no large-sized plants. One population of $A$. dieffenbachii

282 that was found in 1995 was longer in existence, not even as seedlings, in 2010. The newly discovered

283 population of plants on the West Clears contained mainly small plants and seedlings, with only one

284 plant that flowered, and may not be able to support a large weevil population. The decline on Rangatira

285 does not seem to be the result of forest regeneration as the locations of all $A$. dieffenbachii populations

286 are on open grasslands and cliffs where no forest has regenerated. Modeling suggests that if the

287 distance between host-plant populations is great enough to not be easily traversed, but not so far that it

288 is unreachable by the weevils, then the consumer-resource dynamic could persist for the long-term

289 (Johst \& Schöps 2003). The host-plant populations on Rangatira were separated by several hundred

290 meters and the weevil is known to travel up to $500 \mathrm{~m}$ to a new plant resource (Schöps 1998).

291 Therefore, distance between populations does not appear to be the cause of its decline. More intensive 
292 monitoring should be conducted on Rangatira to determine the cause of the host-plant decline and 293 whether the metapopulation dynamic between $H$. spinipennis and A. dieffenbachii has been altered.

294 Hadramphus spinipennis is listed as endangered by the New Zealand Department of Conservation and 295 is considered a species of concern due to its very restricted range. Although spatial models have shown 296 that the weevil population is in equilibrium, and could possibly be classified as "common" (Kean 297 2006), combining genetics with longer-term ecological data does not completely support the notion 298 that H. spinipennis is common on both Mangere and Rangatira. In regards to the number of weevils 299 and host-plant populations on Mangere, the weevil seems relatively abundant; however, on Rangatira 300 lower weevil numbers were found. Genetic data indicates that both populations do not possess a large 301 amount of genetic diversity and have most likely undergone a population bottleneck. Population 302 bottlenecks are related to a loss of genetic diversity which can have significant consequences for long303 term viability of small populations (Grueber et al. 2008). As the forests on Mangere and Rangatira 304 Islands continue to regenerate, A. dieffenbachii may decline due to a loss of open habitat. Although the 305 population counts suggest no change in $H$. spinipennis on Mangere, the weevil may be unable to adapt 306 to a possible decline in its host-plant resulting from the loss of open habitat. This is particularly a 307 concern on Rangatira where a decline in weevil numbers was seen.

\section{Conclusions}

309 A pattern of genetic structure separating a species by island haplotype is something that has been 310 reported in other flightless beetles (Sequeira et al. 2012; Stroscio et al. 2011). Between the two islands

311 there are some genetic differences, which should be preserved if possible, as the H. spinipennis on 312 Rangatira and Mangere Islands are shown to be genetically isolated from each other. The unique 313 haplotypes from each island adds variation and allows for the possibility of cross-introduction of 
314 weevils to preserve genetic diversity. Our results strongly suggest that forest restoration on Rangatira

315 and Mangere Islands has not had a negative impact on H. spinipennis or its host plant; however, a long-

316 term survey, in particular accessing the area on Rangatira that could not be searched in this study, is

317 recommended to confirm small population sizes. Although continued monitoring of the weevil

318 populations is recommended, forest restoration should continue and is not impacting on the

319 conservation of an open habitat specialist.

320 Acknowledgements

321 We thank the Chatham Islands Conservation Board, the Chatham Island imi/iwi, and the Department of

322 Conservation (DoC) for the permit (WE-26391-RES) to collect and for access to the island, housing, 323 and general assistance.

324 References

325 Atkinson IAE. 1990. Ecological restoration on islands: Prerequisites for success. In: Towns DR, 326

Daugherty $\mathrm{CH}$, and Atkinson IAE, eds. Ecological restoration of New Zealand islands. Wellington: Department of Conservation, 73-90. Ecology 13:729-744.

Brower A. 1994. Rapid morphological radiation and convergence among races of the butterfly Ballard JWO, and Whitlock MC. 2004. The incomplete natural history of mitochondria. Molecular Heliconius erato inferred from patterns of mitochondrial DNA evolution. Proceedings of the National Academy of Science 91:6491-6495.

Butler D, and Merton D. 1992. The Black Robin- Saving the world's most endangered bird. Auckland: Oxford University Press. 
335 Craw RC. 1999. Fauna of New Zealand: Molytini Number 39. Lincoln, Canterbury: Manaaki Whenua 336 Press.

337 Darriba D, Taboada GL, Doallo R, and Posada D. 2012. jModel Test 2: More models, new heuristics 338 and parallel computing. Nature Methods 9:772.

339 Department of Conservation. 1999. Chatham Islands Conservation Management Strategy. Wellington $340 \quad$ Conservancy Conservation Management Planning Series No.8.

341 Department of Conservation. 2012. Rangatira (South East Island)2012).

342 Drummond AJ, Suchard MA, Xie D, and Rambaut A. 2012. Bayesian phylogenetics with BEAUti and 343 the BEAST 1.7. Molecular Biology and Evolution 29:1969-1973.

344 Emberson RM, Early JW, Marris JWM, and Syrett P. 1996. Research into the status and distribution of 345 Chatham Islands endangered invertebrates. Science for Conservation:1-28.

346 Folmer O, Black M, Hoeh W, Lutz R, and Vrijenhoek R. 1994. DNA primers for amplification of 347 mitochondrial cytochrome $c$ oxidase subunit I from diverse metazoan invertebrates. Molecular Marine Biology and Biotechnology 3:294-299.

Fountain E, Wiseman B, Cruickshank R, and Paterson A. 2013. The ecology and conservation of Hadramphus tuberculatus (Pascoe 1877) (Coleoptera: Curculionidae: Molytinae). Journal of Insect Conservation 17:737-745.

Frankham R, Ballou JD, and Briscoe DA. 2002. Introduction to conservation genetics. Cambridge: Cambridge University Press.

Goldberg J, and Trewick SA. 2011. Exploring Phylogeographic Congruence in a Continental Island System. Insects 2:369-399. relevance to studies on inbreeding depression in threatened species. Molecular Ecology 17:3978-3984. 
359 Heenan PB, Mitchell AD, de Lange PJ, Keeling J, and Paterson AM. 2010. Late-Cenozoic origin and diversification of Chatham Islands endemic plant species revealed by analyses of DNA sequence data. New Zealand Journal of Botany 48:83-136.

Hitchmough R, Bull L, Cromarty P, and (compilers). 2007. New Zealand threat classification system lists. Threatened Species Occasional Publication, Department of Conservation, Wellington.

Ho SYM. 2007. Calibrating molecular estimates of substitution rates and divergence times in birds. Journal of Avian Biology 38:409-414.

Huson DH, and Bryant D. 2006. Application of phylogenetic networks in evolutionary studies. Molecular Biology and Evolution 23:254-267.

Hutton I, Parkes JP, and Sinclair ARE. 2007. Reassembling island ecosystems: the case of Lord Howe Island. Animal Conservation 10:22-29.

Jamieson IG, Wallis GP, and Briskie JV. 2006. Inbreeding and Endangered Species Management: Is New Zealand Out of Step with the Rest of the World? Conservation Biology 20:38-47.

Johst K, and Schöps K. 2003. Persistence and conservation of a consumer-resource metapopulation with local overexploitation of resources. Biological Conservation 109:57-65.

Kean JM. 2006. Testing models for equilibrium distribution and abundance of insects. New Zealand Journal of Ecology 30:53-60.

Kimura M. 1980. A simple method for estimating evolutionary rate of base substitutions through comparative studies of nucleotide sequences. Journal of Molecular Evolution 16:111-120.

Kimura M. 1981. Estimation of evolutionary distances between homologous nucleotide sequences. Proceedings of the National Academy of Science 78:454-458.

Lanfear R, Calcott B, Ho SYW, and Guindon S. 2012. PartitionFinder: Combined Selection of Partitioning Schemes and Substitution Models for Phylogenetic Analyses. Molecular Biology and Evolution. 
383 Lawton JH. 1997. The Science and Non-Science of Conservation Biology. Oikos 79:3-5.

384 Moriyama E, and Powell J. 1997. Synonymous substitution rates in Drosophila: Mitochondrial versus nuclear genes. Journal of Molecular Evolution 45:378-391.

Papadopoulou A, Anastasiou I, and Vogler AP. 2010. Revisiting the Insect Mitochondrial Molecular

388 Clock: The Mid-Aegean Trench Calibration. Molecular Biology and Evolution 27:1659-1672.

Pertoldi C, Bijlsma R, and Loeschcke V. 2007. Conservation genetics in a globally changing environment: present problems, paradoxes and future challenges. Biodiversity and Conservation 16:4147-4163.

R Development Core Team. 2011. R: A Language and Environment for Statistical Computing. Vienna, Austria.

Ritchie IM. 1970. A preliminary report on a recent botanical survey of the Chatham Islands. Proceedings of the New Zealand Ecological Society 17:52-56.

Rosenberg M, and Anderson C. 2011. PASSaGE: Pattern analysis, spatial statistics and geographic exegesis. Version 2. Methods in Ecology and Evolution 2:229-232.

Schöps K. 1998. Metapopulation dynamics and behaviour of the endangered weevil, Hadramphus spinipennis in relation to its host plant Aciphylla dieffenbachii on the Chatham Islands, New Zealand Doctor of Philosophy. Lincoln University.

Schöps K. 2000. Metapopulation dynamics of the coxella weevil. Science for Conservation 134:1-37. Schöps K. 2002. Local and regional dynamics of a specialist herbivore: overexploitation of a patchily distributed host plant. Oecologia 132:256-263.

Schöps K, Wratten SD, and Emberson RM. 1999. Life cycle, behaviour and conservation of the large endemic weevil, Hadramphus spinipennis on the Chatham Islands, New Zealand. New Zealand Journal of Zoology 26:55-66. 
406 Selkoe KA, and Toonen RJ. 2006. Microsatellites for ecologists: a practical guide to using and

407

408 409

410

411

412

413

414

415

416

417 418

419

420

421

422

423

424

425

426

427

428

429 evaluating microsatellite markers. Ecology Letters 9:615-629.

Sequeira AS, Stepien CC, Sijapati M, and Roque Albelo L. 2012. Comparative Genetic Structure and Demographic History in Endemic Galápagos Weevils. Journal of Heredity 103:206-220.

Simberloff D. 1990. Reconstructing the ambiguous: Can island ecosystems be restored? In: Towns DR, Daugherty $\mathrm{CH}$, and Atkinson IAE, eds. Ecological restoration of New Zealand islands. Wellington: Department of Conservation, 37-51.

Simon C, Frati F, Beckenbach A, Crespi B, Liu H, and Flook P. 1994. Evolution, weighting, and phylogenetic utility of mitochondrial gene sequences and a compilation of conserved polymerase chain reaction primers. Annals of the Entomological Society of America 87:651701.

Sinclair ARE, and Byrom AE. 2006. Understanding ecosystem dynamics for conservation of biota. Journal of Animal Ecology 75:64-79.

Stroscio S, Baviera C, Frati F, Lo Paro G, and Nardi F. 2011. Colonization of the Aeolian Islands by Pimelia rugulosa rugulosa Germar, 1824 (Coleoptera: Tenebrionidae) inferred from the genetic structure of populations: geological and environmental relations. Biological Journal of the Linnean Society 104:29-37.

Tamura K, Peterson D, Peterson N, Stecher G, Nei M, and Kumar S. 2011. MEGA5: Molecular Evolutionary Genetics Analysis using maximum likelihood, evolutionary distance, and maximum parsimony methods. Molecular Biology and Evolution 28:2731-2739.

Taylor AD. 1990. Metapopulations, dispersal, and predator-prey dynamics: an overview. Ecology $71: 429-433$.

Towns D. 2009. Eradications as reverse invasions: lessons from Pacific rat (Rattus exulans) removals on New Zealand islands. Biological Invasions 11:1719-1733. 
430 Towns DR, Bellingham PJ, Mulder CPH, and Lyver POB. 2012. A research strategy for biodiversity 431 conservation on New Zealand's offshore islands. New Zealand Journal of Ecology 36:1-20. 432 Zharkikh A. 1994. Estimation of evolutionary distances between nucleotide sequences. Journal of 433 Molecular Evolution 39:315-329. 


\section{Table 1 (on next page)}

ITS2 primers

Primers developed to amplify a region of the ITS2 gene in H. spinipennis. 
Primer Name Primer Sequence 5' to 3'

Had ITS2 For ATT CTG TTC CCG GAC CAC TCC TGG CTG A Had ITS2 Rev GCG CGC ACC GTT ACR ATC KGA CGY C 
Table 2 (on next page)

Divergence times for the mitochondrial maximum clade credibility tree

Mean divergence times (Ma) and 95\% confidence interval for the two different dating

schemes used to date nodes in the mitochondrial maximum clade credibility tree. Dates were estimated in BEAST using a strict molecular clock with fixed mean rate of 0.0115

substitutions/site/my, and a strict molecular clock with a 3 million year age constraint on the tree root. 
Divergence Times (Ma)

\begin{tabular}{lcc}
\cline { 2 - 3 } & Fixed mean rate & Geological date \\
\hline Mean & 0.0013 & 0.0006 \\
$95 \%$ confidence interval & $0.0000-0.0139$ & $0.0001-0.0016$ \\
\hline
\end{tabular}

2 
Table 3 (on next page)

Aciphylla dieffenbachii populations on Rangatira

Aciphylla dieffenbachii populations found on Rangatira including estimated population size, approximate size of the plants found in the population and whether the plants were in flower. 


\begin{tabular}{lccc} 
Population & A & B & C \\
\hline Number of plants & 10 & 3 to $6^{\mathrm{a}}$ & 2 to 7 and $55^{\mathrm{a}}$ \\
Plant size & medium & $\begin{array}{c}\text { Small } / \\
\text { medium }\end{array}$ & $\begin{array}{c}\text { Small to large } \\
/ \text { seedlings }\end{array}$ \\
Flowering & No & No & Yes $^{\mathrm{b}}$
\end{tabular}

aPopulation B had nine groups of plants spread across a cliff face; each group consisted of 3 to 6 plants. Population $\mathrm{C}$ had five groups of plants patchily distributed with 2 to 7 plants in each group. A total of 55 seedlings were spread throughout the area. ${ }^{b}$ Only two female plants were flowering. 
Table 4(on next page)

Aciphylla dieffenbachii populations on Mangere

Aciphylla dieffenbachii populations found on Mangere including estimated population size, approximate size of the plants found in the population and whether the plants were in flower. 
2

\begin{tabular}{lccccccc} 
Population & 1 & 2 & 3 & 4 & 5 & 6 & 7 \\
\hline Number of plants & 410 & 100 & 180 & 330 & 20 & 150 & 17 \\
\multirow{2}{*}{ Plant Size } & $\begin{array}{c}\text { Small / } \\
\text { medium }\end{array}$ & $\begin{array}{c}\text { Small to } \\
\text { large }\end{array}$ & $\begin{array}{c}\text { Small to } \\
\text { large }\end{array}$ & $\begin{array}{c}\text { Small / } \\
\text { medium }\end{array}$ & Small & $\begin{array}{c}\text { Small / } \\
\text { medium }\end{array}$ & Small \\
& Yes & Yes & Yes & Yes & Yes & Yes & No \\
\hline
\end{tabular}


1

Map of Chatham Islands

Map (1:500,000 scale) of the Chatham Islands with Rangatira (South East) and Mangere Islands labeled. Insert map shows the location of the Chatham Islands in relation to New Zealand.
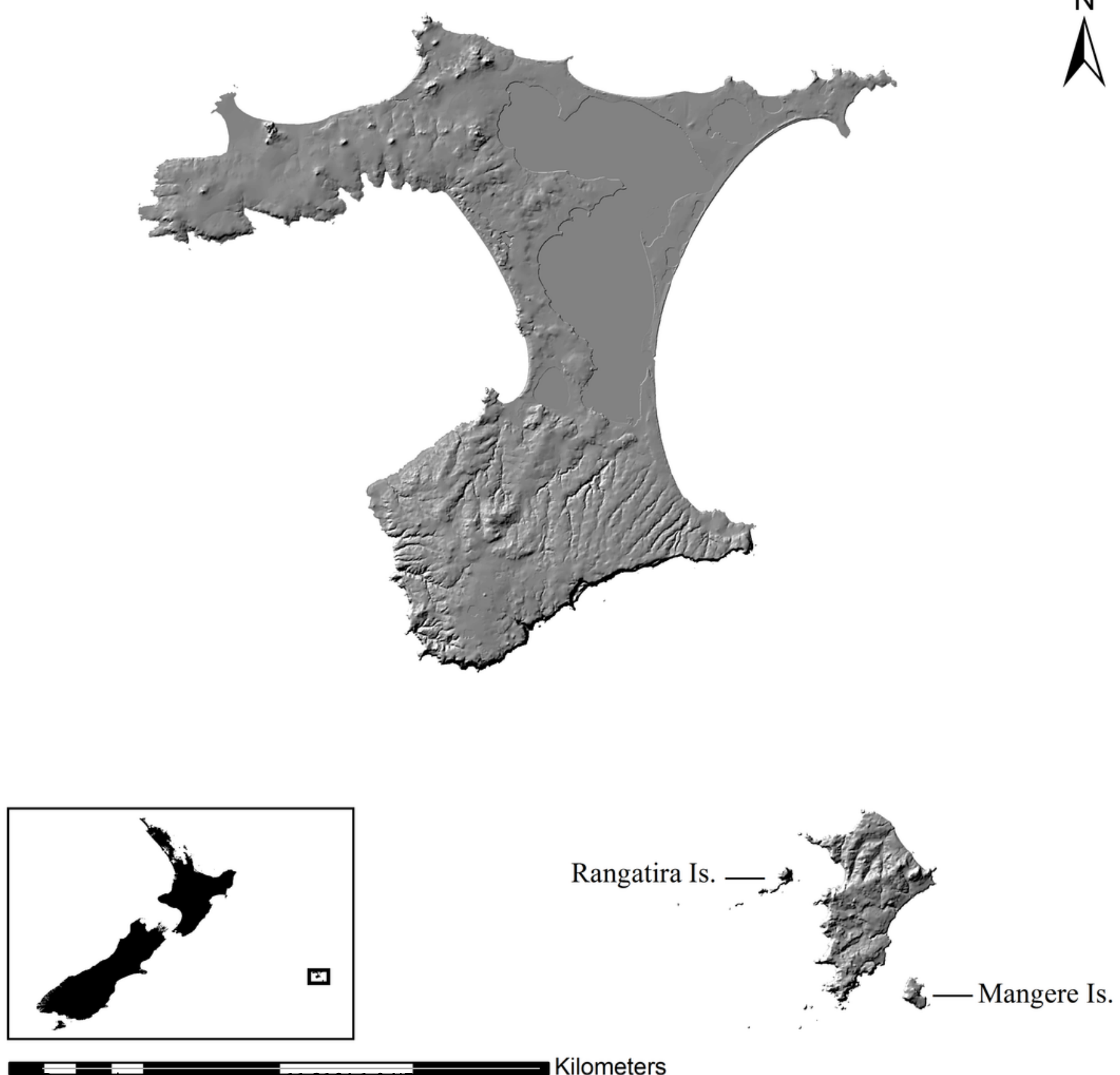
2

Weevil marginal feeding pattern

A photograph depicting the weevil feeding pattern, which is identified by marginal notches.

Photograph by: Jagoba Malumbres-Olarte.

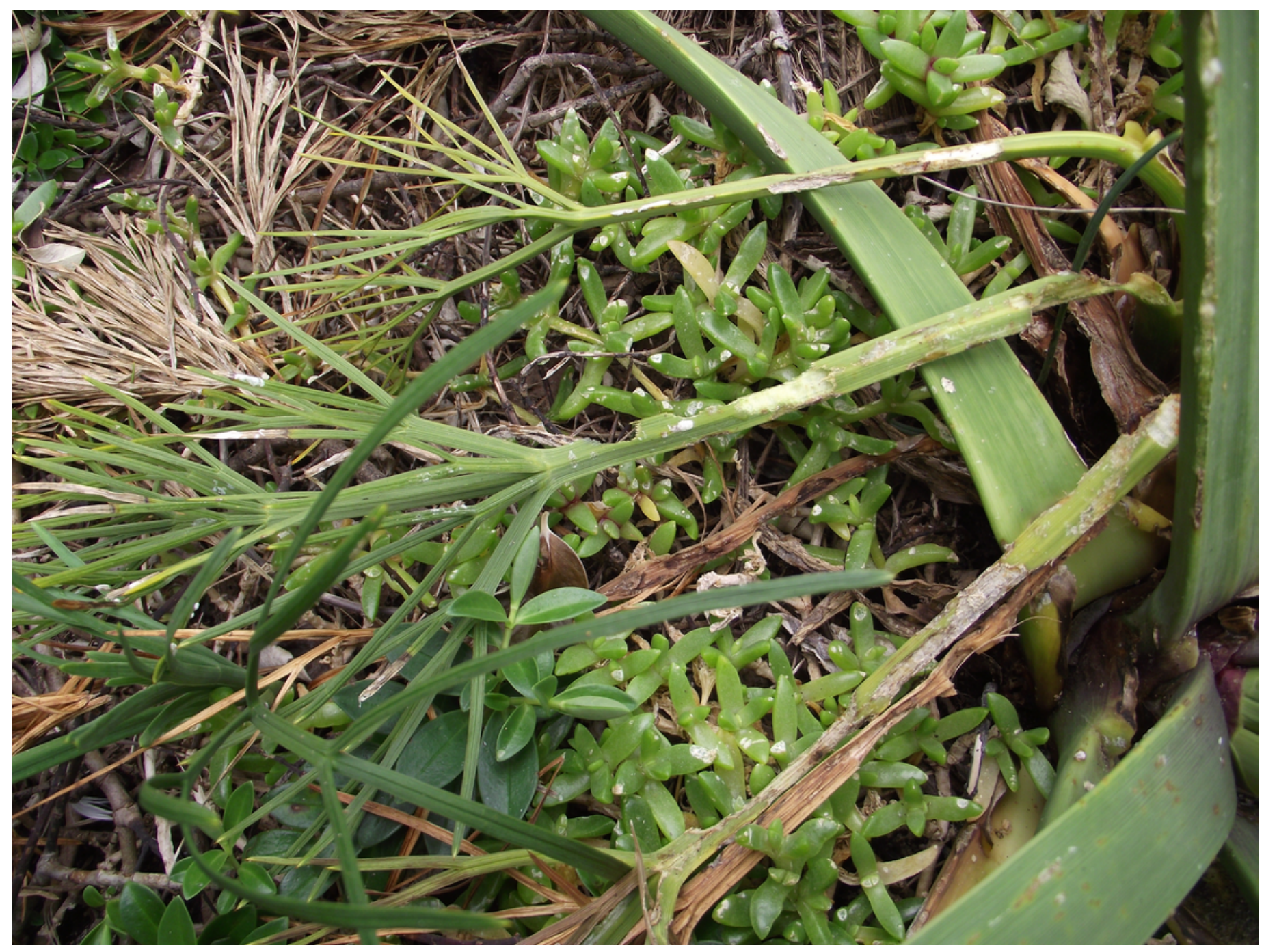




\section{3}

Maps of Rangatira survey sites

Rangatira Island with the populations of $A$. dieffenbachii that were recorded in the 1995 survey by Schöps (2000) (white circles) and the A. dieffenbachii populations found in the 2010 survey (white circles with letters). Letters were assigned to each site as they were found. The triangle with a question mark on the 2010 map represents the one area that could not be surveyed due to adverse weather conditions. Map image was obtained from Google Earth 2013 image and the same image was used for both maps.
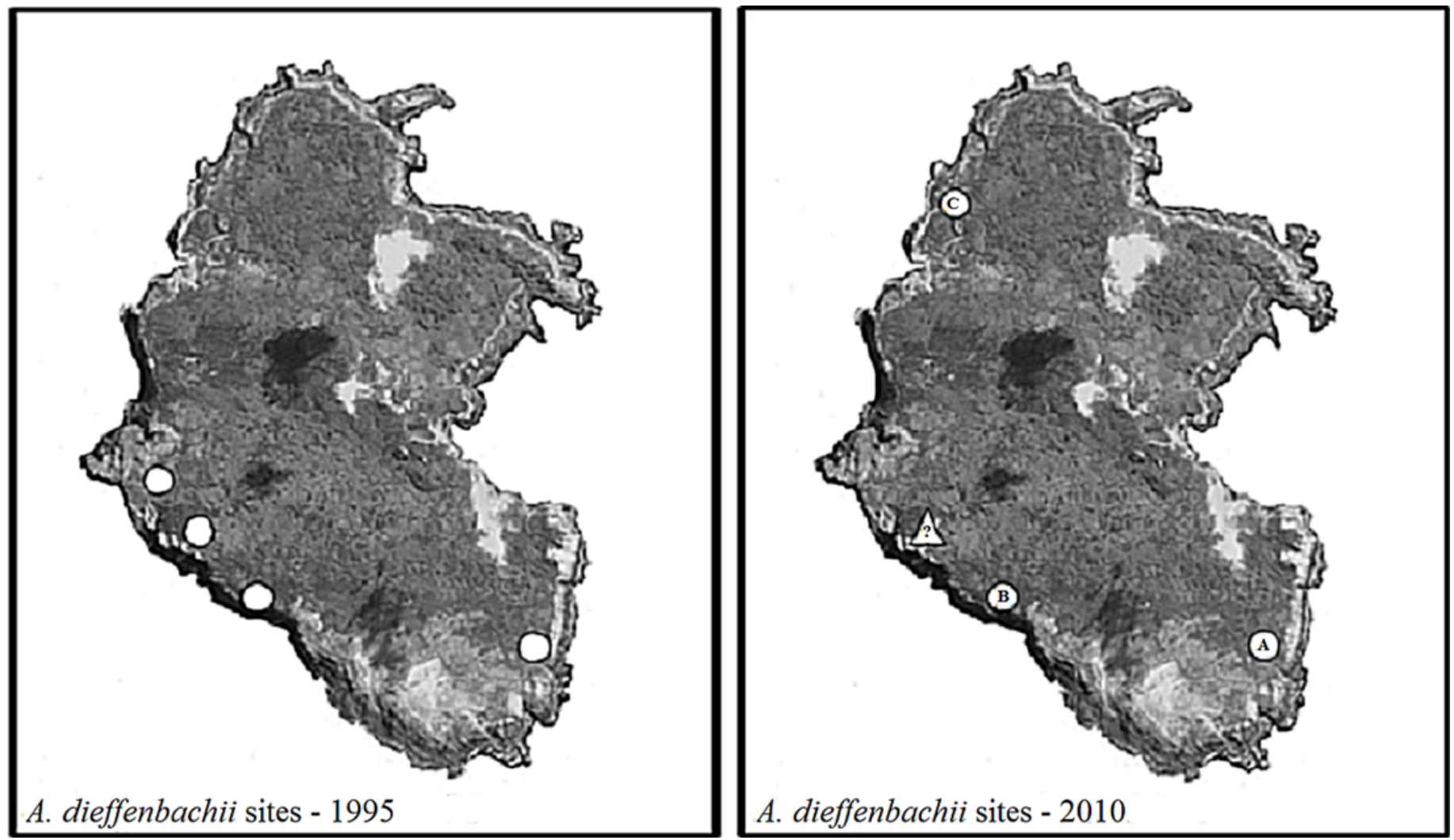
4

Map of Mangere survey sites

Mangere Island with the $A$. dieffenbachii sites that were recorded in the 1995 survey by Schöps (2000) (white areas) and the A. dieffenbachii populations found in the 2011 survey (white areas with numbers representing the larger patches of $A$. dieffenbachii). Numbers were assigned to each site as they were found. The entire island was surveyed visually for $A$. dieffenbachii, but some plant patches could not be reached for hand-searching for weevils. Map image was obtained from Google Earth 2013 image and the same image was used for both maps.
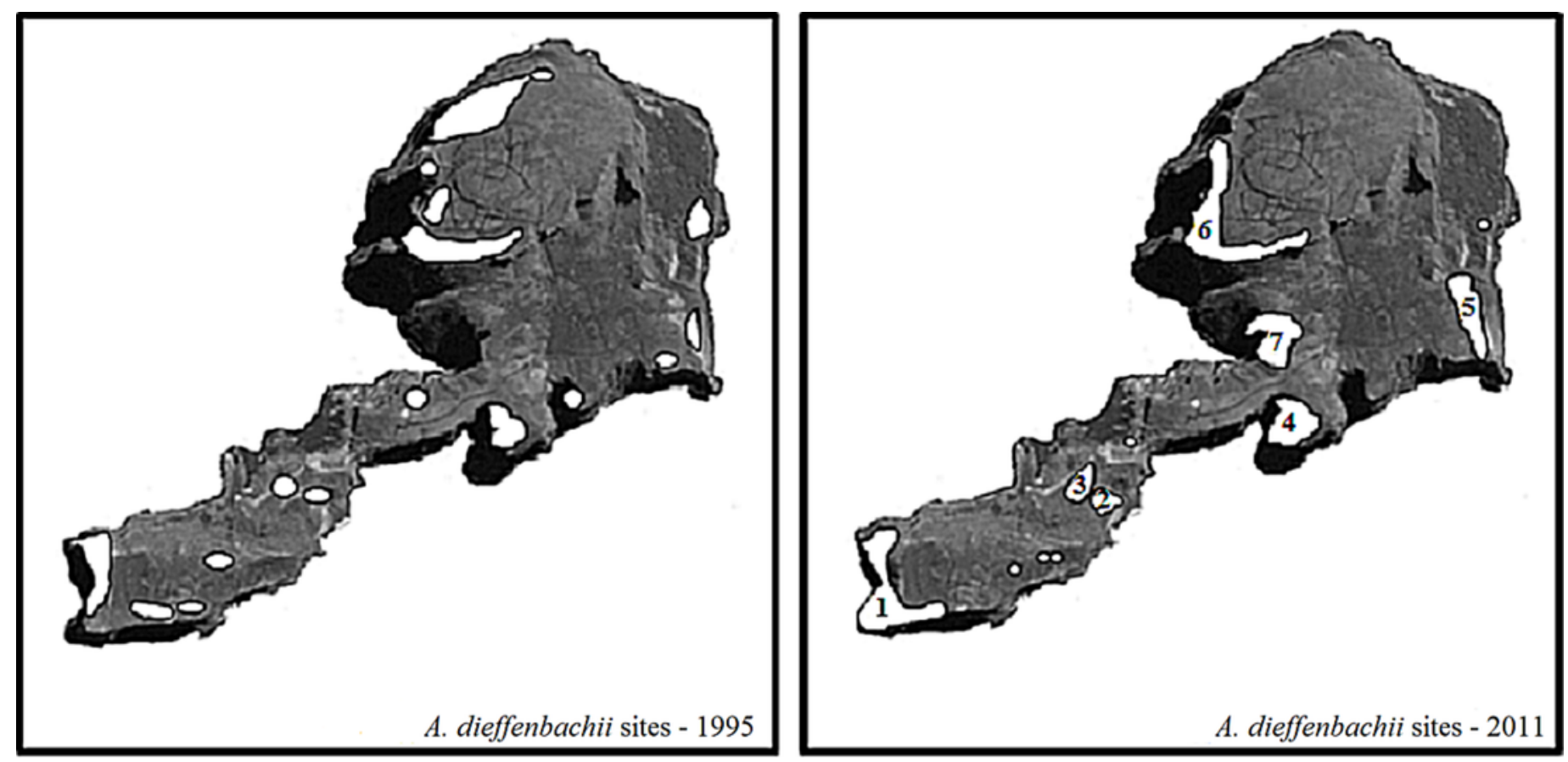


\section{5}

\section{ITS2 Neighbor-Net network}

Neighbor-Net network generated from ITS2 distances. The underlined numbers are individuals from Mangere and the letters are individuals from Rangatira.

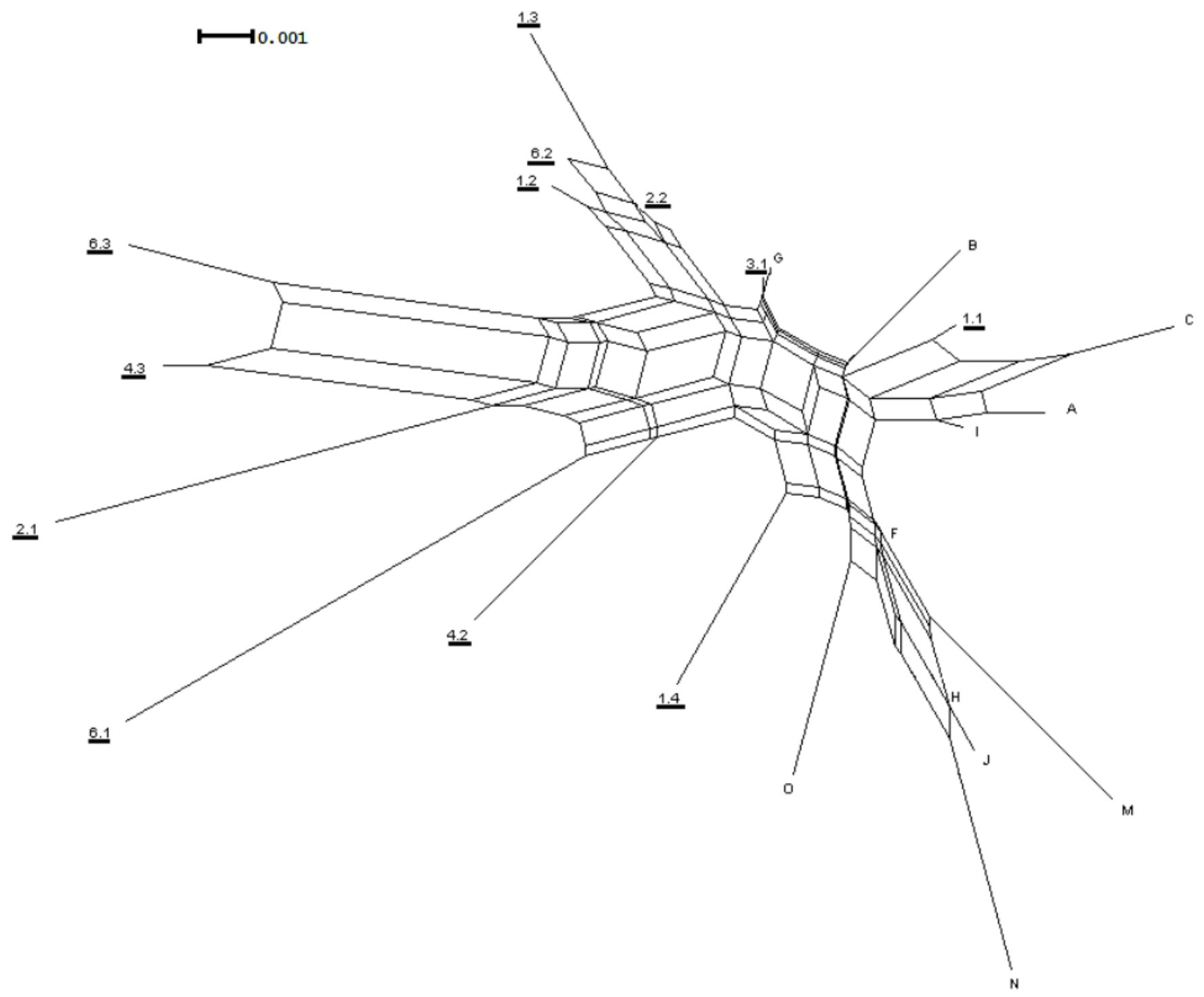




\section{6}

Neighbor joining trees for mitochondrial genes and ITS2

(A) Neighbor joining (NJ) tree for the concatenated mitochondrial genes $\mathrm{COI}$ and cytb. (B) Neighbor joining tree for ITS2. For both trees, individuals from Mangere are underlined (first number of weevil ID is subpopulation and the second number is ID to denote different weevils). The maximum clade credibility tree posterior probabilities higher than $95 \%$ are labeled below the branch node and the bootstrap value for the $\mathrm{NJ}$ tree are above the branch node. The root that was estimated in Beast for the maximum clade credibility tree and it is represented by the grey root line. The scale bar is in substitutions/site.

A)

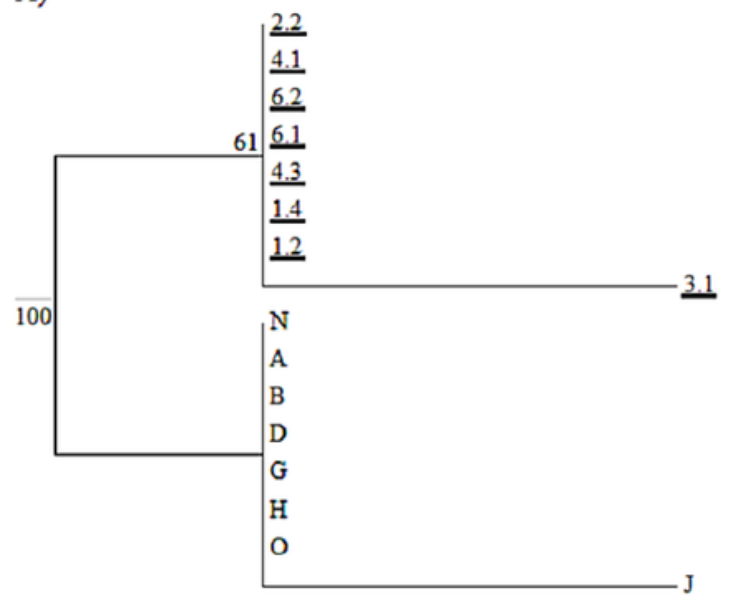

$\stackrel{5}{0.0001}$
B)

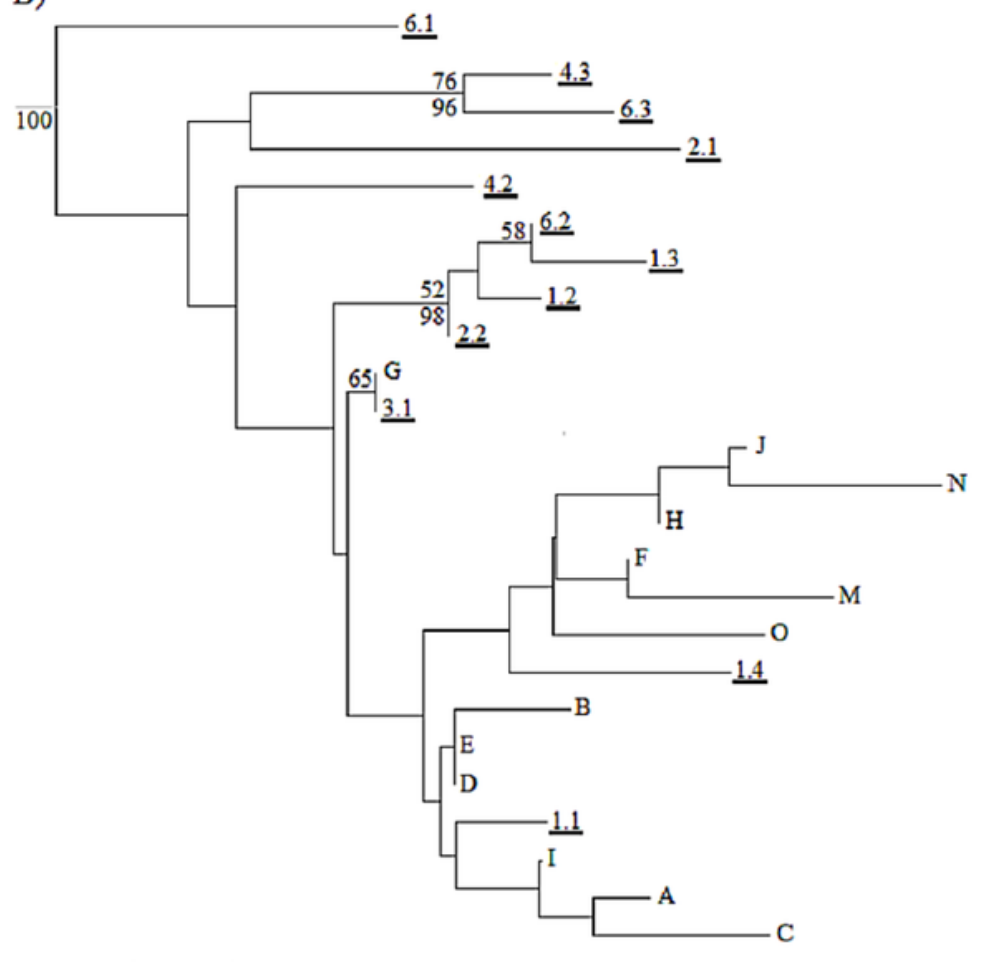

